\title{
POSSIBILITIES OF SMALL WATER RESERVOIR IMPACT IMPROVEMENT ON SURFACE WATER QUALITY IN AGRICULTURAL LANDSCAPE
}

\author{
Michal Kriška Dunajský ${ }^{1}$, Miroslava Pumprlová Němcován, Jana Konečná, \\ Petr Karásek², Jana Podhrázská2
}

${ }^{1}$ Institute of Landscape Water Management, Brno University of Technology, Veveř́ 95, 60200 Brno, Czech Republic ${ }^{2}$ Research Institute for Soil and Water Conservation, Žabovřeská 250, 15627 Praha, Czech Republic

\begin{abstract}
KRIŠKA DUNAJSKÝ MICHAL, PUMPRLOVÁ NĚMCOVÁ MIROSLAVA, KONEČNÁ JANA, KARÁSEK PETR, PODHRÁZSKÁ JANA. 2018. Possibilities of Small Water Reservoir Impact Improvement on Surface Water Quality in Agricultural Landscape. Acta Universitatis Agriculturae et Silviculturae Mendelianae Brunensis, 66(1): 0077-0087.

In the Czech Republic, a significant amount of agricultural landscape nutrients is swept away by surface washes and leakages to subsoil. Subsequently there is a negative influence on surface water quality, where of course also point sources of pollution participate in. Flowing surface water often becomes stagnant while the certain self-purifying processes proceed both in the flowing and stagnant waters. It can be simultaneously stated that the self-purifying process is practically uncontrollable, primarily due to the impact of many entering factors. One of the environmental and technical elements providing quality improvement of water running off a water reservoir is deployment of constructed floating wetlands (CFW). The theoretical background, as well as the laboratory measurements carried out on the test land of the Brno University of Technology in experimental tanks, evidence the significant treatment efficiency of the CFW. Within the research activities, we focused on the general pollution parameters set for surface waters. The first results show that the total phosphorus concentration removal efficiency is $38.8 \%$ after 22 days with employment of the CFW which is a considerably higher value compared to the lysimeter with no CFW where the removal efficiency was only $4.37 \%$. The results can be large-scale applied to most of the small water reservoirs situated in the agricultural landscape.
\end{abstract}

Keywords: agricultural landscape, water reservoir, constructed floating wetlands, self-purifying, nitrogen, phosphorus

\section{INTRODUCTION}

Maintenance of water quality and quantity in the landscape ranks among the crucial environmental issues of the contemporary world. It has adequate scientific, social and political attention. Basically, we recognize point (mostly industrial and communal) and non-point (mostly farming) sources of surface water pollution. With the aim to design complex measures to reduce inputs of chosen matters from all types of sources, a research project started in parts of the Svratka river catchment. This article presents only a part of the project, focused on problems of small water reservoirs. Also discharge from reservoirs (especially ponds) can influence the surface water quality and several of them occur in the model catchment. That is why a specific technical element reducing such outlet of nutrients and unsolved matters is developed with the aim to support wider system of measures on point and non-point surface water pollution sources.

Prior to application measures in real reservoirs, laboratory measurements shall be carried out, followed by a semi-working structure and, conditioned by positive laboratory results. The laboratory measurements have proceeded since 2015 by means of the outdoor test laboratory situated in the test polygon of the Faculty of Civil Engineering of the Technological University in Brno. 
For the research project purposes, several lysimeters (water tanks) are used to simulate and imitate the small water reservoir natural environment. The results mentioned within the article shall be applied in future to the selected areas in order to improve the parameters of waters running off the small water tanks in the agricultural landscape.

Decomposing processes proceed under the specific conditions in the water reservoirs and, in most cases, the quality of water running off the agricultural landscape enhances. Growing water biomass (mostly unicellular algae or cyanobacteria) contains accumulated phosphorus and nitrogen. However, the algae are not retained in the water reservoir. The reservoirs seem to be practically an insignificant element in the long-term nutrient balance point of view. Not to mention the necessity of mineral sediment removal and return to the agricultural land. One of the alternatives how to partially retain suspended solids (also unicellular algae) is simple equipment called constructed floating wetlands (CFW).

The equipment principle consists in shielding the water surface with a floating carrier in combination with wetland plants. It is assumed that the plants take nutrients and the root system serves as a biofilm carrier supporting the nitrogen form changes. Nutrients are gradually consumed (degraded) during the standard natural self-purifying processes. The benefit of the plentiful plant root system floating in water is the similarity to the filter environment. Simultaneously, the covered water surface prevents the sunlight from entering the water and supports the respiration process of the green algae. As a result, oxygen is consumed, and, under the specific conditions, the anaerobic environment is created. The anaerobic environment benefit resides in the denitrification process, i.e. transformation of nitrate to nitrogen gas released to atmosphere. The balance of total nitrogen running off the water tank is therefore reduced. Our results show that the values of chemical oxygen demand (COD), suspended solids (SS), nutrients and chosen parameters are effectively reduced.

\section{Theoretical background}

Special attention has been recently worldwide attracted to water treatment technologies directly in the water structures (e.g. Vymazal, 2010; Headley and Tanner, 2012; Zhang et al., 2014; Schöntag et al., 2015). Theoretically, when observing the nutrient balance in the watercourse, the nutrients are only partially accumulated in the bottom sediments and they are mostly dissolved and running off with the surface flowing water. As the watercourse flow rate decreases and the surface water gradually becomes stagnant (a small water reservoir, pond, wetland, moat, etc.), the nutrient balance can significantly change as eutrophication shakes concentrations of all known nutrient forms.

One of the alternatives how to affect a quantity of runoff of dissolved nutrients and suspended solids is the worldwide applied technology of CFW. The CFW principles are as follows:

- presence of a light carrier floating on the water surface serving as a water surface cover against the sunlight,

- planting of the carrier with wetland plants which take available nutrients off the water environment,

- plant root system works as a filter and reduces the suspended solids content,

- vegetation enhances transfer of oxygen to the substrate (Vymazal, 2013), releases and forms organic acids and influences the $\mathrm{pH}$ value by adding the $\mathrm{CO}_{2}$ during respiration (Vymazal, 2010).

Published positive results also point out reduction of the $\mathrm{N}-\mathrm{NO}_{3}, \mathrm{~N}-\mathrm{NH}_{3}, \mathrm{~K}$ and suspended solids concentrations under the CFW with the dominating bulrush cover (Typha spp.). The CFWs are the innovative environmental approach to control of water quality decrease due to spot but mainly areal pollution sources (Hubbard et al., 2011; Rangarajan et al., 2012). The CFW implies wetland plants but also zooplankton and periphyton naturally colonizing the root system.

The CFW technology is the environmental approach leading to reduction of both point and non-point recipient pollution sources. This type of technology has recently come under the spotlight. Tens of surveys and implementations were carried out all over the world; however, despite the evidenced positive effect, seeking of reliable efficiency represents a large research gap. Regarding the research results and implementations in the Czech Republic, the Brno University of Technology is historically the first workplace which has experience in the CFWs, even though based on the laboratory results only yet (Němcová and Kriška Dunajský, 2016). Environmental pollution poses the significant hazard to sustainable development of many countries, not only in the western world. One of the first references on the CFW describes the experimental research equipment (Nakamura et al., 1995) held to enhance the water quality thanks to four major functions:

- water treatment,

- maintenance of the specific biotope for water and wetland animal species,

- protection against bank line abrasion (in ponds, reservoirs, watercourses),

- positive influence on landscape elements (primarily extension of species composition).

The technology potential is mostly mentioned in the literature in relation to variable waste water flow rates (Hubbard et al., 2004; Todd et al., 2003). There the CFWs are intended to retain mainly suspended solids in the unified sewer and rainwater drainages. The processes proceeding during the CFW application were described in the extensive surveys (Vymazal, 2010). Efficiency of pollutant removal by means of the CFW was evaluated by many various 
authors (above all e.g. Tanner and Headley, 2011; Headley and Tanner, 2008).

The major contribution of the treatment effect consists in presence of the plants capable of water treatment by means of root system aerating, $\mathrm{H}^{+}$ release to the water environment, organic acid forming and releasing together with the $\mathrm{CO}_{2}$ production during the respiration process (Zhang et al., 2014; Vymazal, 2007). The positive results on COD (chemical oxygen demand) reduction by up to $85 \%$ have also been often published (Chen et al., 2013) where the experiments were carried out on the artificially made waste water using the winter ryegrass (Lolium perenne). The effects related to reduction of the $\mathrm{N}-\mathrm{NH}_{4}{ }^{+}$concentration were recorded by Sun, Liu and Jin (2009) while the environment characteristics were very similar to our water tank arrangements (lysimeters) and application. These authors evidenced the efficiency of $96.7 \%$. Zhao et al. (2012) measured efficiency of the total nitrogen $\left(\mathrm{N}_{\text {tot }}\right)$ removal in the stagnant water in combination with the mixture of plants and it reached $50.3 \%$. On the contrary, the very high treatment efficiency values on the nutrient-added water are presented by the authors (Keizer-Vlek et al., 2014) where the efficiency of the $N_{\text {tot }}$ reduction reached up to $98 \%$. The other observed nutrients also comprise $\mathrm{N}-\mathrm{NH}_{4}{ }^{+}$. However, the results often vary depending on the initial concentration, treated water source, applied plant species and other parameters. Not very positive efficiency values (35\%) were evidenced by the authors Van de Moortel et al. (2010). Contrarily, the extreme quality efficiency of $99.6 \%$ was reached by Xian et al. (2010) or $99.4 \%$ by the authors Zhou et al. (2012). Last but not least, the total phosphorus value $\left(\mathrm{P}_{\text {tot }}\right)$ is also observed and also here the resulting efficiency values often vary depending on the external boundary conditions. The lowest efficiency of the $\mathrm{P}_{\text {tot }}$ removal between 8 and $15 \%$ was published for instance by (Yang et al., 2008). But incomparably more positive values of $92 \%$ were reached by the authors (Keizer-Vlek et al., 2014) or 82-98.5\% by (Sooknah and Wilkie, 2004).

For our research purposes, the most important information is that the authors recorded the summer algae flowering in the check water tanks (without the water surface cover) and the minimum algae advance growth in the water tanks with the CFW covering the water surface. Shimada et al. (2007) developed two types of CFWs designed for emersed vegetation. Their findings proved that the water quality enhancement thanks to deployment of the CFW could also cause expansion of natural vegetation and suppression of extension of the area covered by the CFW initially. Stewart et al. (2008) published the results describing the capabilities of bacteria growing in the root systems of plants (planted on the CFW). The bacteria are capable of daily removing of up to $10,600 \mathrm{mg}$ nitrates, $273 \mathrm{mg}$ ammonia, $428 \mathrm{mg}$ phosphates per $0.16 \mathrm{~m}^{3}$ of the root zone volume. Another survey focused on heavy metals evidenced that the CFW are able to remove released copper compounds from 3.8 to $6.4 \mathrm{mg}$ per square meter (of the CFW) a day and zinc compounds from 25 to $88 \mathrm{mg}$ per square meter a day (Headley, Tanner, 2008). It was also proven that, thanks to the vegetation, $20.2 \%$ of total phosphorus was removed from already eutrophicated waters (Song et al., 2009).

The CFWs are the innovative environmental solution to mitigate the water quality decrease due to both point and non-point pollution sources (Headley, Tanner, 2012; Hubbard et al., 2011; Rangarajan et al., 2012). The system comprises the floating carrier and environmental populations - macrophytes, invertebrates, zooplankton and biofilm (Faulwetter et al., 2011; Hubbard et al., 2011; Kato et al., 2009). The CFW can be applied to most of the water treatment plants and to the wide range of water structures (Tanner, Headley, 2011). The general treating functions of the CFW are presented by the plant adsorption, periphyton and root filtration (Borne et al., 2013; Headley, Tanner, 2012). The pollutants are removed in the water tank by means of sedimentation, assimilation of algae and bacteria and adsorption to the bottom sludge (Shilton, 2006; Wetzel, 2001).

The present plants constitute one of the important parts of the CFW technology. While selecting the plant species composition, many factors have to be taken into account, including but not limited to: climatic conditions, nutrient sensitivity, direct sunlight sensitivity, root length, density and volume, emersed biomass, plant buoyancy force, polluted water type and concentration, substrate absence in the root zone, water retention ability and biomass growth rate both above and under the water surface.

To design the CFW technology, the crucial prerequisite is the knowledge of the stagnant water quality where the CFW will be placed. For example, Konečná et al. (2017) evaluated the following amount of nutrients load to water bodies evoked by soil erosion in the Jihlava river catchment (area $1155 \mathrm{~km}^{2}$ ): $\mathrm{P}_{\text {tot }}=168.6 \mathrm{t}$ per year, $\mathrm{N}_{\text {tot }}=79.8 \mathrm{t}$ per year. Possibilities to influence water quality affected by extreme storms by CFWs were studied e.g. by Headley and Tanner (2008). When the nutrients are caught in the water reservoir, the eutrophication issue arises. Therefore, the $\mathrm{P}_{\text {tot }}$ value is mentioned as one of the most significant factors (it is $79.9 \%$ out of the total eutrophication factor) leading to the eutrophication behaviour (Huang et al., 2017). Requirements for permanently higher agricultural production have led to excessive use of $\mathrm{N}$ and $\mathrm{P}$ in a number of agri-food production systems all around the world (Bouwman et al., 2009; Mekonnen and Hoekstra, 2015; Smith, 2003). Therefore, we seek a solution to prevent nutrients from travelling along the basin or to retain nutrients effectively in the both existing and new small water reservoirs in the agricultural landscape. 


\section{MATERIALS AND METHODS}

The research objective consists in development of equipment of which the major contribution and function is to improve water quality in the water reservoirs. It is supposed that CFW will be created and placed in chosen ponds in the Svratka river catchment. But first, several test CFWs have been successively prepared to serve for additional laboratory measurements and consequent relocation to the location situated in the real working conditions.

The material selection for the CFW implementation takes into account few general factors while special attention was mainly paid to wide-range practicality and applicability. The typical materials (in the world-wide range) to construct a CFW are for instance polystyrene foam, closed-cell PVC or PP pipes, polystyrene slats, bamboo, sealed PET bottles or inflatable rubber bags. Finally, non-granular polystyrene was selected as a floating carrier because no negative impact of the material on the water quality has been evidenced when used as a filter medium (Schöntag et al., 2015). On the contrary, polystyrene is used as a filter medium to treat drinking water. Therefore, the minimum negative impact can be assumed.

Prior to the production start of a functional sample to be used for semi-working measurements, a full-grown CFW with the two-year root system was utilized for testing. Plants of two-year hard rush (Juncus inflexus) were chosen for the experiment. The plants were planted well ahead in the rain water tank fertilized with the unmeasured nutrient quantity. Fig. 1 shows the robust root system of the hard rush reaching the length up to $1 \mathrm{~m}$. The very dense root mass reaches the length of $60 \mathrm{~cm}$.

Globular polystyrene of $30 \mathrm{~mm}$ thickness was used as a carrying medium for prepared wetland plants. Each test tank with the CFW was covered from approximately $97 \%$ by the carrier. The tanks were filled with water from chosen polluted pond from the Svratka river catchment (see the parameters in Tab. I). This pond was selected based on the prior field survey and it was evaluated as the worst location in the quality point of view from the available reservoirs.

To carry out the survey, we used test tanks of the internal volume of $\mathrm{V}=90 \mathrm{l}$ and the size of $30 \times 80 \times 35 \mathrm{~cm}$ (width $\times$ length $\times$ height) each . The tank bottom and side walls of two of them were thermally insulated with $10 \mathrm{~cm}$ thick polystyrene which simulates the real conditions and eliminates the ambient temperature impact with consequent undesirable result distortion. The volume of experimental tanks was chosen according to the experience of authors who dealt with the research of CFW efficiency, e.g. Wang and Sample (2014) or Billore and Prashant Sharma (2009). Purposefully we fulfilled almost whole the tank with the root system because we focused at "living filter". In conformity with findings of other researchers (e.g. Pavlineri, Skoulikidis, Tsihrintzis, 2017) we suppose that the water space will be divided into three parts: filtrating, anaerobic (below roots) and free space without a CFW cover. The tanks with plant roots simulates filtrating space. It actually represents first step of experiments and they will continue next years in bigger tanks (600 l), in 3 repetitions of every variant. Finally, the effect of CFW will be measured in conditions of a real pond.

- The testing focused on comparison of three types of water tanks (lysimeters) and the CFW impact on the quality of several selected and commonly observed parameters. Three arrangements comprise:

- Test water tank 1 (L01) - with free surface: simulating the standard water reservoir conditions. Free surface enables cyanobacteria, algae as well as submerged vegetation to grow.

- Test water tank 2 (L02) - with a CFW: simulating the water reservoir treatment with equal and area-wide covering of the stable water reservoir with the CFW system.

- Test water tank 3 (L03) - no CFW in the winter period: the same water used to fill the test water tanks, placed in the cooling equipment at the temperature of $\mathrm{T}=4^{\circ} \mathrm{C}$, simulating behaviour of the stabilization of reservoir during cold (winter) period with no sunlight (e. g. with shielding, under the ice layer, etc.).

The check experiment L03 mainly served for comparison of the micro-organism activity and for evaluation of the self-purifying process. The experiment with the CFW placed on the cold water shall take place in winter 2017/2018. Nevertheless, we assume the minimum nutrient offtake by plants as well as the negligible micro-organism activity in the winter period. We only expect to detect the water filter process by the root zone.

The measurements were carried out in spring 2016. In initial phase, some basic characteristics ( $\mathrm{pH}$, $\mathrm{T}, \mathrm{O}_{2}, \mathrm{ORP}$ ) were measured several times every day. After the system stabilisation the water samples were subsequently taken from the experiment start after 3-8-10-17-19-22 days. The samples were analysed

I: Applied wateranalysis results

\begin{tabular}{|c|c|c|c|c|c|c|c|c|c|c|}
\hline Turbidity & $\begin{array}{c}\text { Total } \\
\text { oxygen }\end{array}$ & ORP & $\mathbf{p H}$ & $\mathrm{NO}_{3}^{-}$ & $\begin{array}{c}\text { Sample } \\
\text { temperature }\end{array}$ & $\begin{array}{c}\text { Air } \\
\text { temperature }\end{array}$ & $\mathbf{N}-\mathbf{N H}_{4}{ }^{+}$ & COD & $\mathbf{P}_{\text {tot }}$ & TOC \\
\hline FNU & $\mathbf{m g} \cdot \mathbf{l}^{-1}$ & $\mathbf{m V}$ & - & mg..$^{-1}$ & ${ }^{\circ} \mathbf{C}$ & ${ }^{\circ} \mathbf{C}$ & mg.1 ${ }^{-1}$ & mg. $\mathbf{l}^{-1}$ & mg.1 ${ }^{-1}$ & mg. $\mathbf{l}^{-1}$ \\
\hline
\end{tabular}


immediately after the sampling. The following parameters were observed during the experiment: - chemical oxygen demand (COD),

- total organic carbon (TOC),

- total phosphorus content $\left(\mathrm{P}_{\text {tot }}\right)$,

- ammoniacal nitrogen content $\left(\mathrm{N}-\mathrm{NH}_{4}{ }^{+}\right)$,

- oxidation - reduction potential (ORP),

- dissolved oxygen $\left(\mathrm{O}_{2}\right)$,

- acidity (pH),

- turbidity,

- temperature (T).

These parameters are typically used for the assessment of surface water quality. Concentrations of $\mathrm{N}$ and $\mathrm{P}$ were analysed by the DR 3900 spectrophotometer, next water characteristics were measured by means of submersible probes and multimeter (HACH HQ40d) or the HACH 2100Q IS turbidimeter.

\section{RESULTS}

The experiment in water tanks is conducted as a long term one. Further results for the first year 2016 are presented. Obtained values are presented in Figs. 2-7. Calculated CFW efficiency (rate of pollution decrease) in chosen parameters is apparent from Tab. II. Some water quality characteristics (e.g. turbidity) were measured more often.

Concerning the COD parameter, no significant difference was observed among the individual lysimeters (Fig. 2). For instance, the COD decreasing efficiency was $73.0 \%$ after 22 days with floating plants and $73.9 \%$ without floating plants. Biochemical
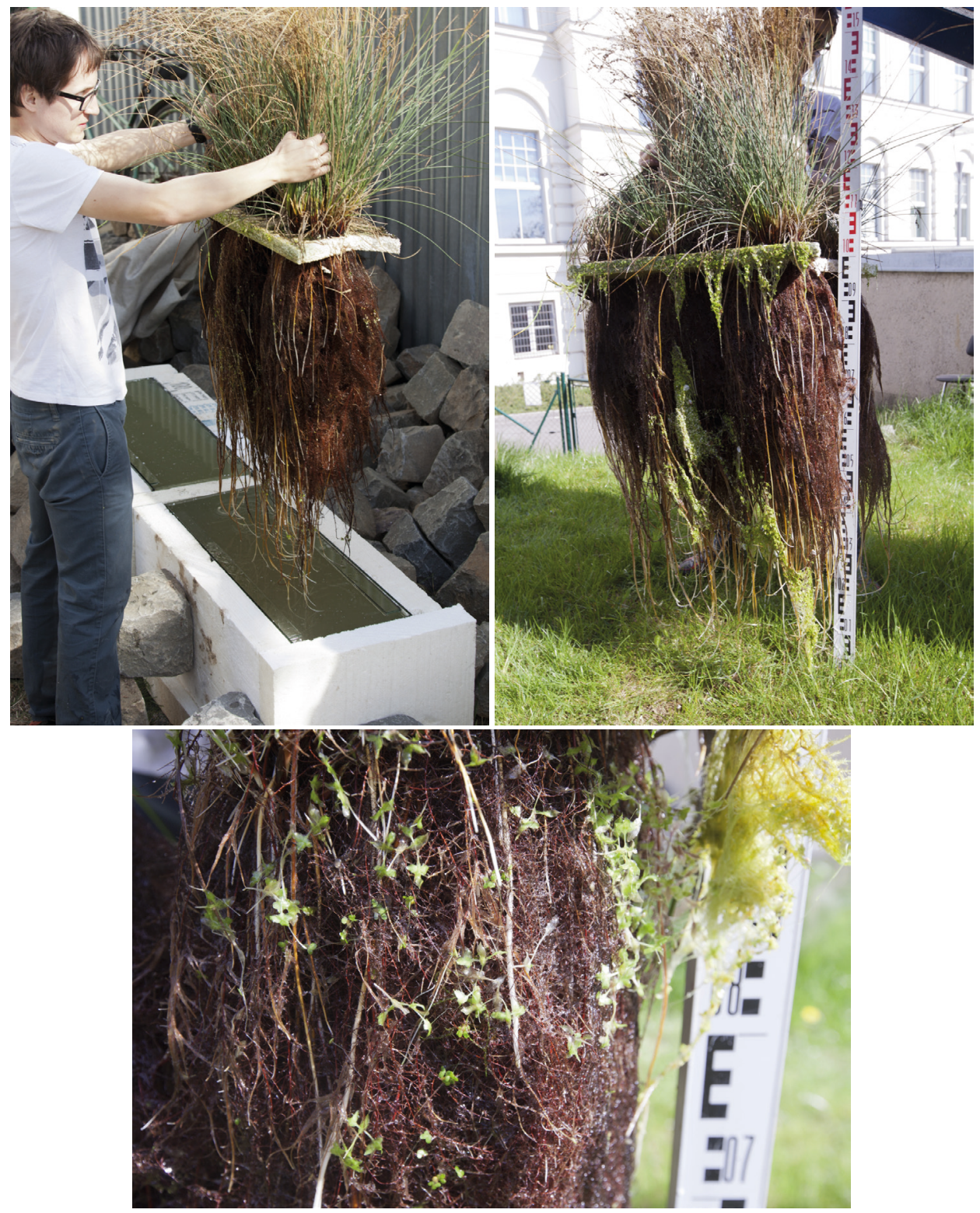

1: Root system of two-year hard rush before application to the test CFW 
processes suppression (caused by the low temperature of $4{ }^{\circ} \mathrm{C}$ ) only brought by the same time the removal efficiency of $60.9 \%$. Due to a possibility of external substances input (pollen, dust), the removal efficiency measured by the lysimeter L03 during the first 18 days was even higher. For instance, the removal efficiency measured on the tenth day by L03 was $49.4 \%$ with present plants, and $61.1 \%$ in case of L03. Consequent equalization of differences between L01 and L02 was very likely caused by oxygen transmission through the water surface as well as by a higher sunlight intensity.

Concerning the total phosphorus removal, the results show considerable differences compared

\begin{tabular}{lcccccc}
\hline & \multicolumn{5}{c}{ Pollution removal efficiency \% } \\
\hline \multirow{3}{*}{$\mathbf{N}^{-} \mathbf{N H}_{4}{ }^{+}$} & Darameter & Day & $\mathbf{7}$ & $\mathbf{1 3}$ & $\mathbf{2 1}$ & $\mathbf{2 7}$ \\
& L01 & -10 & 17 & 34 & 51 \\
& L02 & 86 & 100 & 100 & 100 \\
COD & L03 & -19 & -7 & -9 & -2 \\
& L01 & 66 & 69 & 74 & 70 \\
& L02 & 46 & 55 & 73 & 71 \\
$\mathbf{P}_{\text {tot }}$ & L03 & 60 & 58 & 61 & 63 \\
& L01 & -1 & -2 & 4 & 2 \\
\hline
\end{tabular}

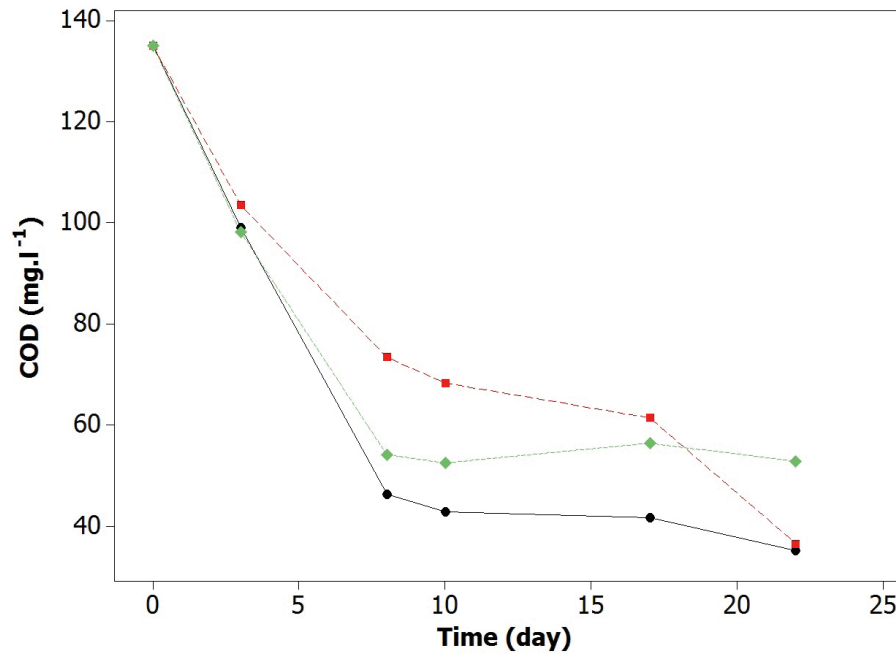

Typ

2: Time-dependent changes of the $\operatorname{COD}\left(m_{g} . l^{-1}\right)$

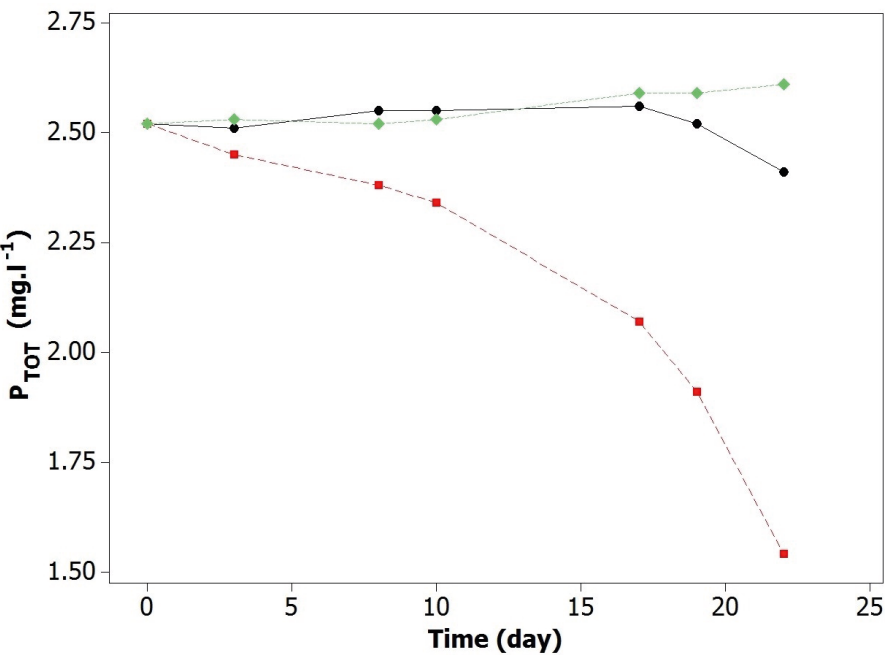

3: Time-dependent changes of the $P_{\text {tot }}\left(m g . l^{-1}\right)$ concentration 
to the COD parameter. As shown in Fig. 3 and Tab. II, the phosphorus removal intensity is significantly higher in the water tank with plants (L02) compared to the other tanks. The obvious difference of the measured $\mathrm{P}_{\text {tot }}$ values among the individual test tanks was found out already during the first week from the commencement of the tests. Although the values vary by tens of milligrams only, they become significant results after recalculation to the removal efficiency values. For instance, during the retention period of 8 days, the removal efficiency was $5.6 \%$ only (at L02) and zero values were measured in the other tanks.

When water was retained in the root system for next 7 days (i. e. 17 days altogether), the removal efficiency for $\mathrm{P}_{\text {tot }}$ is $17.8 \%$ and $38.9 \%$ after 22 days with the plants. The other tanks showed the highest removal efficiency after 22 days with the value of $4.4 \%$ (L01). We can also observe gradually decreasing concentration in L01 where the self-purifying capabilities of biological active water supposedly started to come through.
The similar results, as the $\mathrm{P}_{\text {tot }}$ values, were also found out with $\mathrm{N}-\mathrm{NH}_{4}{ }^{+}$(Tab. II). During observation, concentrations intensively decreased only at presence of floating plants in L02. The original pollution levels of $25.30 \mathrm{mg} . \mathrm{l}^{-1}$ dropped after 3 days of retention only to $13.5 \mathrm{mg} . \mathrm{l}^{-1}\left(25.1 \mathrm{mg} . \mathrm{l}^{-1}\right.$ at LO1 and $27.2 \mathrm{mg} . \mathrm{l}^{-1}$ in L03), after 8 days to $3.57 \mathrm{mg} . \mathrm{l}^{-1}$ and 27.8 and 29.4 mg..$^{-1}$ (Fig. 4). The rising values in L01 and L03 can be caused by expiring anaerobic decomposition of organic mass on days when insufficient oxygen quantity was transferred through the water surface. The very positive results were reached in the test tanks planted with the wetland plants. After 17 days, the lysimeter shows the efficiency of $99.8 \%$ (concentration of $0.06 \mathrm{mg}^{-1} \mathrm{l}^{-1}$ ) and the efficiency after 22 days is even higher than $99.9 \%$ (the concentration value is lower than 0.02 mg. $\left.\mathrm{l}^{-1}\right)$.

Concerning the other measured parameters which are not evaluated for efficiency purposes, no significant differences among the individual test tanks were found out. We have not even expected
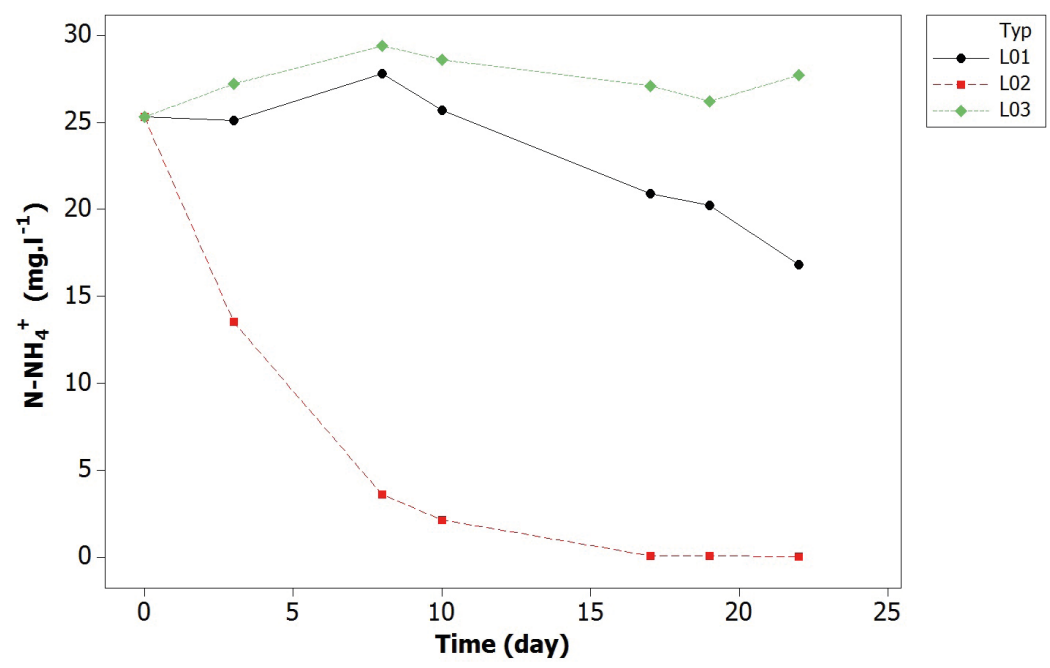

4: Time-dependent changes of the $\mathrm{N}-\mathrm{NH}_{4}^{+}\left(m g . l^{-1}\right)$ concentration

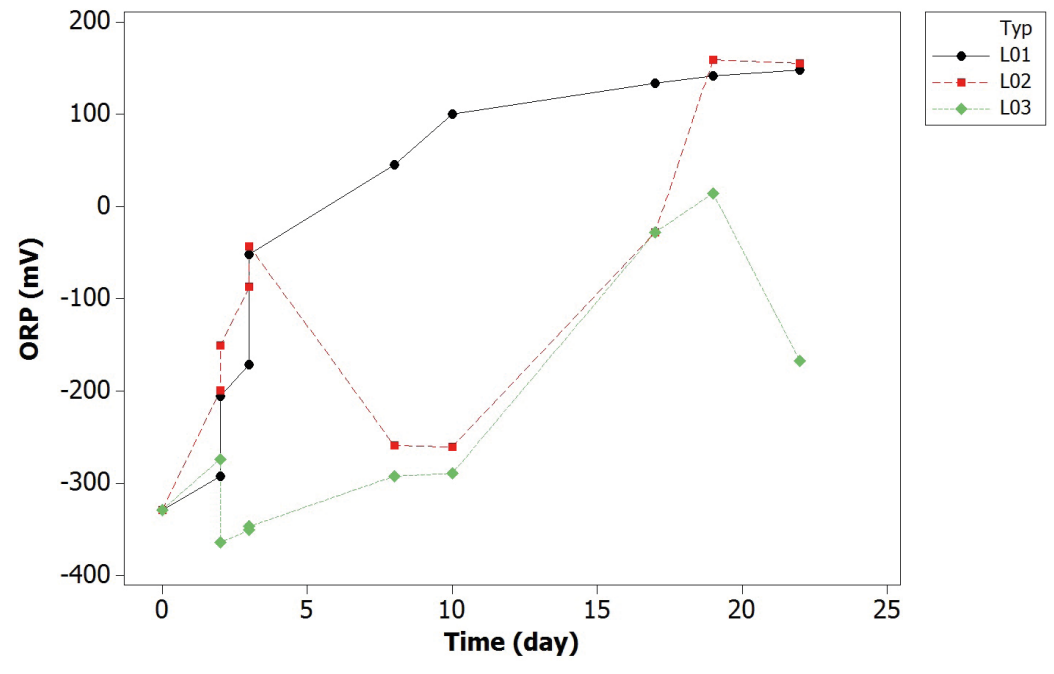

5: Time course of $\mathrm{ORP}(\mathrm{mV})$ 
significant differences among the ORP parameter values as there should be the environment with no free dissolved oxygen under the covered water surface. The ORP values, however, rose from the deep negative values to the oxidation potential values in all test tanks (Fig. 5). It seems that environment in tanks was unstable (with fluctuating values) up to the fifth day.

The identical conclusions can be applied to the measured turbidity (Fig. 6). The turbidity values slowly decreased from the initial 89.20 FNU to the final 5.10-4.1-20.7 FNU after 22 days. During the first week, the value of L01 and L03 even increased, very likely due to partial development of the unspecified algae or bacteria clusters. The highest measured values were 156 FNU (L01) and 134 FNU (L03).

The other results such as the course of the total organic carbon (TOC, mg.l-1 $)$, dissolved oxygen $\left(\mathrm{O}_{2}, \mathrm{mg}^{-1} \mathrm{l}^{-1}\right)$, pH development $(-)$ and water temperature $\left(\mathrm{T},{ }^{\circ} \mathrm{C}\right)$ can be found below. The results serve as additional information to state hypotheses for the major, above mentioned courses of N, P and COD concentrations.

It is evident by the TOC time course (Fig. 7) that the retention period shows mostly the positive character. Nevertheless, there can be a situation when the values start rising, very supposedly due to unicellular algae growth. The best results were reached in the test tank L02; the plants despite their capability of doping the water while respiration $\left(\mathrm{CO}_{2}\right)$ also proved the positive impact on the TOC general development.

Another chart in Fig. 7 evidences the assumption of oxygen transmission suppression when the water surface is covered. It is becoming apparent that when the water surface is totally bare, aeration is more efficient thanks to the natural oxygen transmission through the water surface. The plants are not obviously capable of supplying such a large amount of oxygen in comparison to oxygen delivered transfer across open water level. The $\mathrm{O}_{2}$ concentration in L02 after 22 days was $4.65 \mathrm{mg} . \mathrm{l}^{-1}$, and even doubled up to $9.06 \mathrm{mg} . \mathrm{l}^{-1}$ in L01. The result confirms assumption of formation of less aerated conditions under CFW compared to the free water level. If an organic biomass (green algae) occurs in water environment, an anaerobic environment is expected.

The $\mathrm{pH}$ course does not show the significant effect as the values mostly oscillate between 7.2 and 8.5. The $\mathrm{pH}$ values decrease in the L02 tank during the first 14 days, however, the values consequently approach the other test tank values.

The temperature development $\left({ }^{\circ} \mathrm{C}\right)$ also evidences our hypothesis as well as the external results. When the water surface is covered, the water environment is thermally insulated and, simultaneously, the plants start vaporing, i.e. the latent heat is leaking by transpiration.

\section{DISCUSSION}

The first results show the significantly higher efficiency at the $\mathrm{N}-\mathrm{NH}_{4}^{+}$pollution removal. Although the space under the CFW should contain the anaerobic environment followed by the lower ammonia nitrogen efficiency, our outputs contrarily evidence the strong nitrification capabilities compared to water exposed to the bare water surface (accompanied by impact of sunlight, oxygen transmission by water surface, etc.). The L02 test lysimeter exposed to stagnant water shows the efficiency of $86 \%$ after only 7 -day exposure. The value shall be understood as specific for the set initial and boundary conditions, primarily with respect to absence of the flowing environment. But we can state that this value verges on results published by Zhou et al. (2012) - 99.4\% of the efficiency. Contrarily Van de Moortel et al. (2010) found out the ammonia $\mathrm{N}$ removal only up to $35 \%$ in similar experiment.

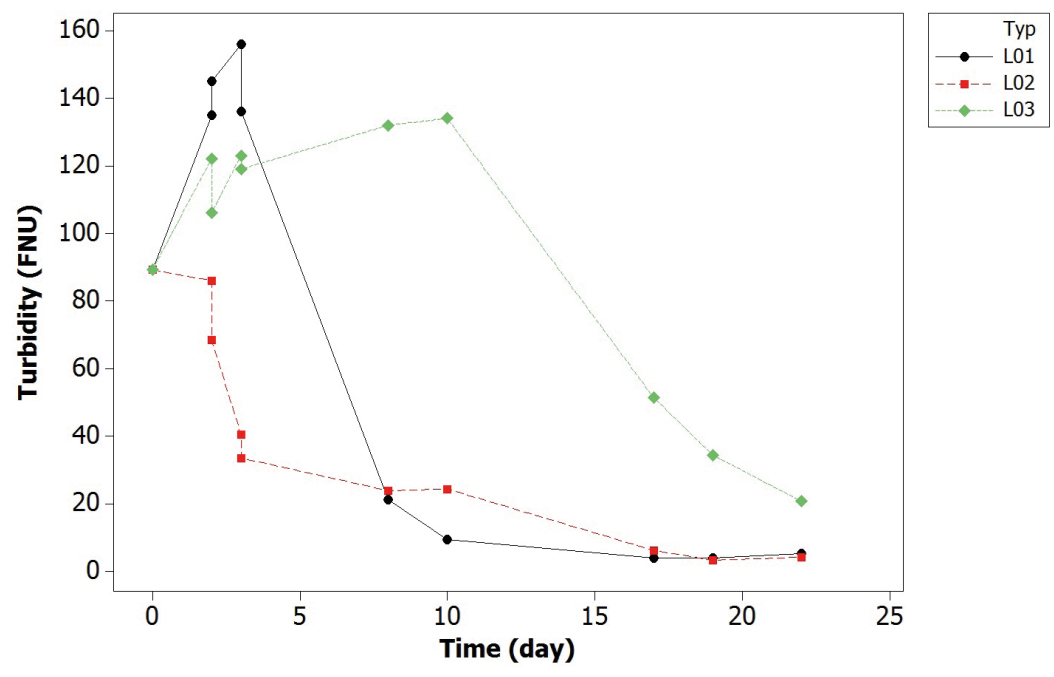

6: Time course of turbidity (FNU) 
There are no significant differences in the COD parameter values. It can be assumed that when the flowing environment is employed (CFW installed in front of the drainage structure), efficient filtration will be ensured by the root system which will very supposedly retain suspended solids primarily causing the COD pollution. Some positive changes of COD could vary e.g. from 53\% (Van de Moortel et al., 2010) to 85\% (Chen et al., 2013).

The appreciated result is the high efficiency of the total phosphorus removal $\left(\mathrm{P}_{\text {tot }}\right)$. In case of the lysimeter with the placed CFW, the removal efficiency reaches up to $50 \%$ after one-month exposure. In the real conditions, the results will also be affected by many external impacts and input factors. According to the results of Keizer-Vlek et al. (2014), CFWs have potential to remove up to $92 \%$ of $\mathrm{P}_{\text {tot }}$, or even $98.5 \%$ (Sooknah and Wilkie, 2004). Also positive influence of CFWs on other studied parameters ( $\mathrm{pH}$, turbidity, ...), implying water quality, is confirmed by many authors (e.g. Ran, Agami, Oron, 2004, Pavlineri, Skoulikidis, Tsihrintzis, 2017).

The CFWs are applied frequently, primarily to treat heavily polluted waters, in order to catch floating pollutants in rain water tanks, road washes or diluted waste waters, etc. (e.g. Zhang et al., 2014, Van de Moortel et al., 2010, Pavlineri, Skoulikidis, Tsihrintzis, 2017). Although the CFWs have not been largely utilized in the water reservoirs in the agricultural landscape yet, a positive impact on quality of water running off the basin with the intensive agricultural activities can be assumed based on the evidenced efficiency. These results usually lean on experiments in water tanks (Polomski et al., 2009, Stewart et al., 2008). There is lack of knowledge of CFWs capability to improve water quality in ponds or reservoirs in landscape. Vymazal (2007) studied processes of removal and retention of $\mathrm{P}$ and $\mathrm{N}$ in different conditions with following conclusions. Single-stage constructed wetlands cannot achieve high removal of total nitrogen due to their inability to provide both aerobic and anaerobic conditions at the same time. Vertical flow constructed wetlands remove successfully ammonia $\mathrm{N}$ but a very limited denitrification takes place in these systems. On the other hand, horizontal-flow constructed wetlands provide good conditions for a denitrification but the ability of this system to nitrify ammonia is very limited. Removal of total phosphorus varied between 40 and $60 \%$ in all types of constructed wetlands.
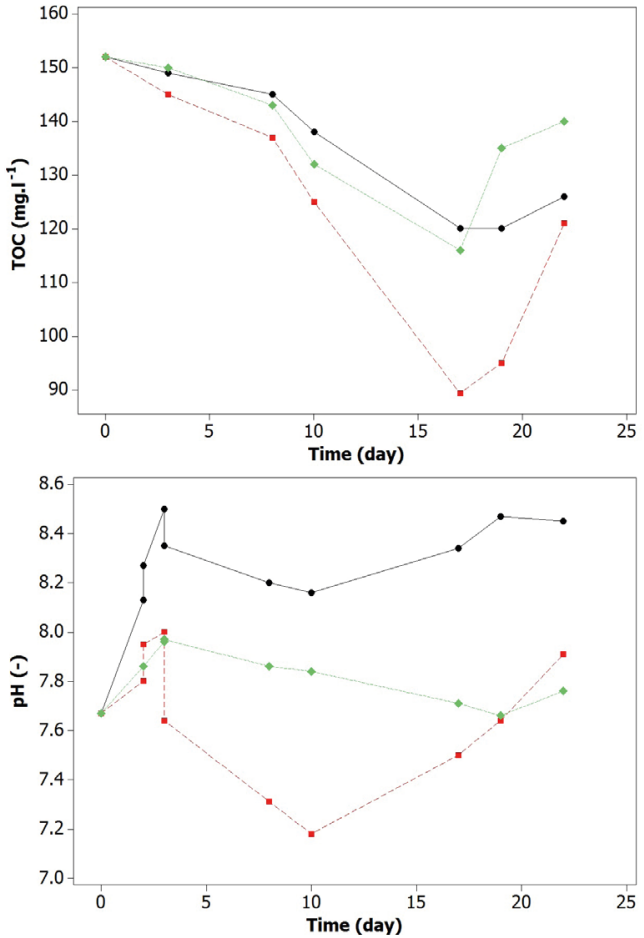

7: Time course of values of TOC $\left(m g . l^{-1}\right), O_{2}\left(m g . l^{-1}\right), p H, t\left({ }^{\circ} \mathrm{C}\right)$

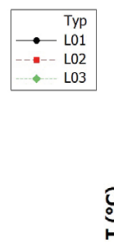

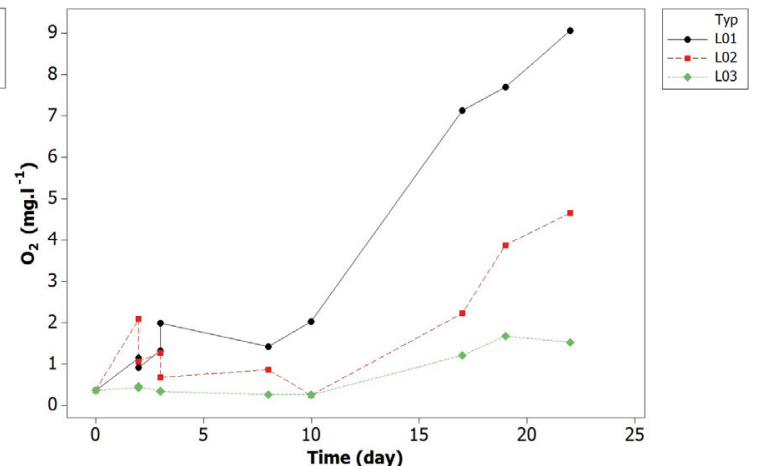

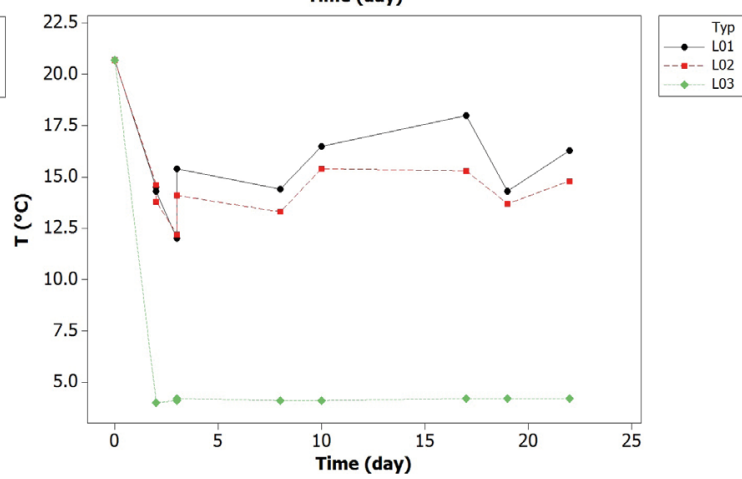

$$
\text { ) }
$$




\section{CONCLUSION}

Water reservoirs are important elements of the Czech landscape with many ecological functions. On the other side the nutrients running off the agricultural land are the significant issue that can lead up to stagnant water eutrophication. It is crucial to solve the issue at the point of origin. Therefore, the nutrients have to be removed from surface waters as soon as possible to prevent contamination of other surface waters. In a case when various agrotechnical, organizational and other measures are uneconomical, we can seek solutions leading to elimination of runoff pollution. The situations where a surface watercourse flows into a reservoir can be technically solved by means of floating islands. The runoff pollution concentration can be effectively reduced in this way. In fact, the water reservoir becomes an equipment improving the nutrient balances in the agricultural landscape thanks to co-influence of the natural self-purifying processes.

The CFWs, as proven by many foreign surveys, keep catching floating pollutants effectively throughout a year. Growth of unicellular algae is not imminent in the Czech Republic climate in the winter period. Nevertheless, mineral suspended solids can run off the reservoir during the whole year. In such a case, the root system of the present floating vegetation functions as a filter system only. The issue that we will focus on during the upcoming project stages is management of the plant biomass produced above the water surface. The 2016/2017 winter period showed that the foamed polystyrene is not vulnerable to frost exposure. Thanks to the moisture-proof characteristics, the polystyrene does not decompose to smaller particles. However, it could decay due to the direct sunlight in the summer period. But the sunlight is eliminated (reduced) by the present vegetation. Most of the carrier area gets covered already during the second vegetation period.

The CFWs are developed and tested in the frame of the research project aimed at design of complex measures for mitigation of impact of point and non-point sources on surface water pollution. It is supposed that the CFWs will be installed in chosen ponds in model catchments of the project.

\section{Acknowledgement}

The paper was supported by the Ministry of Agriculture in the frame of the project QJ1620040 Optimization of water and soil protection in water source basins considering maintainable systems of agricultural management. Simultaneously a part of the analyses was supported by the grant FAST-S-15-2850 Effect of waste water on groundwater quality.

\section{REFERENCES}

BILLORE, S. K. and PRASHANT SHARMA, J. K. 2009. Treatment performance of artificial floating reed beds in an experimental mesocosm to improve the water quality of river Kshipra. Water Sci. Technol., 60(11): 2851-2859.

BORNE, K. E., FASSMAN, E. A. and TANNER, C. C. 2013. Floating treatment wetland retrofit to improve stormwater pond performance for suspended solids, copper and zinc. Ecological Engineering, 54: 173-182.

BOUWMAN, A. F., BEUSEN, A. H. W. and BILLEN. G. 2009. Human alteration of the global nitrogen and phosphorus soil balances for the period 1970-2050. Global Biogeochemical Cycles, 23(1): 1-16.

CAO, W. and ZHANG, Y. Removal of nitrogen (N) from hypereutrophic waters by ecological floating beds (EFBs) with various substrates. Ecological Engineering, 62: 148-152.

CHEN, C., ZHANG, R., WANG, L., WU, W. and CHEN, Y. 2013. Removal of nitrogen from wastewater with perennial ryegrass/artificial aquatic mats biofilm combined system. Journal of Environmental Science, 25(4): 670-676.

FAULWETTER, J. L., BURR, M. D., CUNNINGHAM, A. B., STEWART, F. M., CAMPER, A. K. and STEIN, O. R. 2011. Floating treatment wetlands for domestic wastewater treatment. Water Science Technology, 64(10): 2089-2095.

HEADLEY, T.R. and TANNER, C.C. 2008. Application offloating wetlands forenhanced stormwatertreatment: A review. New Zealand: Auckland Regional Council Technical Publication, p. 93.

HEADLEY, T. R. and TANNER, C. C. 2012. Constructed wetlands with floating emergent macrophytes: an innovative stormwater treatment technology. Critical Reviews. Environmental Science and Technology, 42(21): 2261-2310.

HUANG, J., XU, CH., RIDOUTT, B. G., WANG, X. and REN, P. 2017. Nitrogen and phosphorus losses and eutrophication potential associated with fertilizer application to cropland in China. Journal of Cleaner Production, 159: 171-179.

HUBBARD, R. K., ANDERSON, W. F., NEWTON, G. L., RUTER, J. M. and WILSON, J. P. 2011. Plant growth and elemental uptake by floating vegetation on a single-stage swine wastewater lagoon. Transactions of the ASABE, 54(3): 837-845.

HUBBARD, R. K., GASCHO, G. J. and NEWTON, G. L. 2004. Use of floating vegetation to remove nutrients from swine lagoon wastewater. Transactions of the ASAE, 47(6): 1963-1972. 
KATO, Y., TAKEMON, Y. and HORI, M. 2009. Invertebrate assemblages in relation to habi- tat types on a floating mat in Mizorogaike Pond, Kyoto. Japan. Limnology, 10: 167-176.

KEIZER-VLEK, H. E., VERDONSCHOT, P. F. M., VERDONSCHOT, R. C. M. and DEKKERS, D. 2014. The contribution of plant uptake to nutrient removal by floating treatment wetlands, Ecol. Engineering, 73: 684-690.

KONEČNÁ, J., KARÁSEK, P., FUČÍK, P., PODHRÁZSKÁ, J., POCHOP, M., RYŠAVÝ, S. and HANÁK, R. 2017. Integration of soil and water conservation measures in an intensively cultivated watershed - a case study of Jihlava river basin (Czech Republic). European Countryside, 1(1): 17-28.

MEKONNEN, M. M. and HOEKSTRA, A. Y. 2015. Global gray water footprint and water pollution levels related to anthropogenic nitrogen loads to fresh water. Environmental Science and Technology, 49(21): 12860-12868.

NAKAMURA, K., SHIMATANI, Y., SUZUKI, O., OGURI, S. and YASUMOCHI, T. 1995. The ecosystem of an artificial vegetated Island, Ukishima, in Lake Kasumigaura. In 6th Int. Conf. of Lakes - Kasumigaura'95 Proc., 1: 406-409.

NĚMCOVÁ, M. and KRIŠKA DUNAJSKÝ, M. 2016. Development of constructed treatment wetlands in Czech Republic for five years term. In: Ecology, Economics, Education and Legislation. SGEM conference proceedings. Sofia: STEF92 Technology Ltd., pp. 225-232.

PAVLINERI, N., SKOULIKIDIS, N. and TSIHRINTZIS, V. 2017. Constructed floating wetlands: A review of research, design, operation and management aspects, and data analysis. Chemical Engineering Journal, 308: 1120-1132.

POLOMSKI, R. F., TAYLOR, M. D., BIELENBERG, D. G., BRIDGES, W. C. and KLAINE, S. J. 2009. Nitrogen and Phosphorus Remediation by Three Floating Aquatic Macrophytes in Greenhouse-Based LaboratoryScale Subsurface Constructed Wetlands. Water, Air, and Soil Pollution, 197(1-4): 223-232.

RAN, N., AGAMI, M. and ORON, G. 2004. A pilot study of constructed wetlands using duckweed (Lemna gibba L.) for treatment of domestic primary effluent in Israel. Water Research, 32(9): 2241-2248.

RANGARAJAN, S., SAMPLE, D.J., BOONE, M., LEE, J., MUNEER, A., NARAYANASWAMY, K. and HOCHSTEDLER, M. 2012. Urban wet-weather flows. Water Environmental, 84(10): 861-970.

SCHÖNTAG, J. M., PIZZOLATTI, B.S., JANGADA, V. H., DE SOUZA, F. H. and SENS, M. L. 2015. Water quality produced by polystyrene granules as a media filter on rapid filters. Journal of Water Process Engineering, 5: 118-126.

SHILTON, A.N. 2006. Pond Treatment Technology. IWA Publishers.

SHIMADA, Y., FUKURO, S. and KUBOTA, H. 2007. Improvement of lake water quality and ecosystems through use of composite vegetated floating islands. Journal of Water and Waste 49(7): 612-618.

SMITH, V. H. 2003. Eutrophication of freshwater and coastal marine ecosystems: a global problem, Environmental Science and Pollution Research, 10(2): 126-139.

SONG, Y.W., NIAN, Y. G., HUANG, M. S. and NIE, Z. D. 2009. Effects of substrates and plants on pollution removal of constructed wetlands. Journal of Environmental Engineering, 3(7): 1213-1217.

SOOKNAH, R. D. and WILKIE, A. C. 2004. Nutrient removal by floating aquatic macrophytes cultured in anaerobically digested flushed dairy manure wastewater. Ecological Engineering 22: 27-42.

STEWART, F. M., MULHOLLAND, T., CUNNINGHAM, A. B., KANIA, B. G. and OSTERLUND, M. T. 2008. Floating islands as an alternative to constructed wetlands for treatment of excess nutrients from agricultural and municipal wastes - results of laboratory-scale tests. Land Contamination and Reclamation, 16(1):25-33. 